\title{
The Flexi Planar Fuel Cell
}

\author{
C. Kalyvas ${ }^{1}$, T. Mason ${ }^{2}$, C. Gibbs ${ }^{2}$, D. Brett ${ }^{2}$ and A. Kucernak ${ }^{1}$ \\ ${ }^{1}$ Department of Chemistry, Faculty of Natural Sciences, Imperial College London. \\ ${ }^{2}$ Department of Chemical Engineering, Faculty of Engineering, University College London.
}

\begin{abstract} characteristics for short modules have been successfully demonstrated.

\section{INTRODUCTION}

The current geometrical design of a common fuel cell is not fault tolerant and requires all components to operate in an almost ideal manner. This is because each power generating unit in a fuel cell stack is connected in series: the weakest link in the fuel cell chain dictates performance and reliability. If a fuel cell is like a string of batteries all connected in a line, then that fuel cell can only operate as well as the worstperforming of all of the batteries. When one of the batteries fails, the entire fuel cell fails. Therefore we need to make sure that the membrane electrode assemblies (MEAs) do not fail during the operational life of the fuel cell stack. This makes the fuel cell electrodes very difficult to produce and contributes significantly to their cost.
\end{abstract}

The Flexi Planar fuel cell is a new type of lightweight polymer electrolyte fuel cell design. The approach utilises standard, reliable and low cost printed circuit board fabrication processes. An iterative approach is adopted and feasibility along with excellent test

Keywords Flexi planar fuel cell/stack; Modular configuration; Polymer electrolyte fuel cell; Printed circuit board technology

But what if we could design a fuel cell stack so that we can switch out bad units and allow the fuel cell to continue operation? Such a fuel cell would then show fault tolerance and resilience to adverse environmental and internal influences. This is what the flexi planar fuel cell concept is all about. The project aims to radically redesign how fuel cells operate. This can allow us to have much greater control of the fuel cell operation compared to the configuration used almost exclusively everywhere else. An interesting byproduct of the new design is that we can integrate the power control electronics directly with the fuel cell achieving significant space savings. In order to produce this new type of fuel cell, a link is required between both Chemistry and Chemical Engineering aspects of the work. The development of new types of electrodes is guided by some subtle chemistry associated with the production of 'throughmembrane' connectors, while a different type of housing is required for the integration of electrodes into a stack. The project consortium is made up of a very experienced team composed of experts in fuel cell science and engineering as well as power electronics from both Imperial College London and University College London.

Through an iterative approach, this enterprise has been proven successful by demonstrating feasibility, excellent test characteristics for short modules and achieving technological proof points over the first two phases of the project. Extensive progress has also been made on the study of the long-term performance and durability of flexi planar cells, modules and materials.
Future technical work will involve the incorporation of initial electronic boards for each module. The system is aiming for automotive and micro-fuel cell applications where the high power density will be particularly advantageous.

\section{INNOVATIVE CONCEPT AND ADVANTAGES}

The flexi planar stack allows substantial reductions on both the stack and system level:

- the approach is MEA agnostic and can be applied to both proton and hydroxide conducting polymer electrolyte fuel cells

- the approach requires no seals, contains internal manifolding and employs very low cost and high-capacity manufacturing techniques

- the stack is fault tolerant: the system should continue working under extreme events (e.g. Failure of a fuel cell electrode or entire layers of the stack)

The stack design, Fig. 1, presents the following advantages:

- Mass-manufacturable today

- Simplified stack bill of materials (compression \& sealing)

- Low-cost stack components

- Patented, low-cost copper passivation layer

- Control flexibility of modules with integrated electronics

- High gravimetric power density

- Flexible design for integration into several industrial applications 


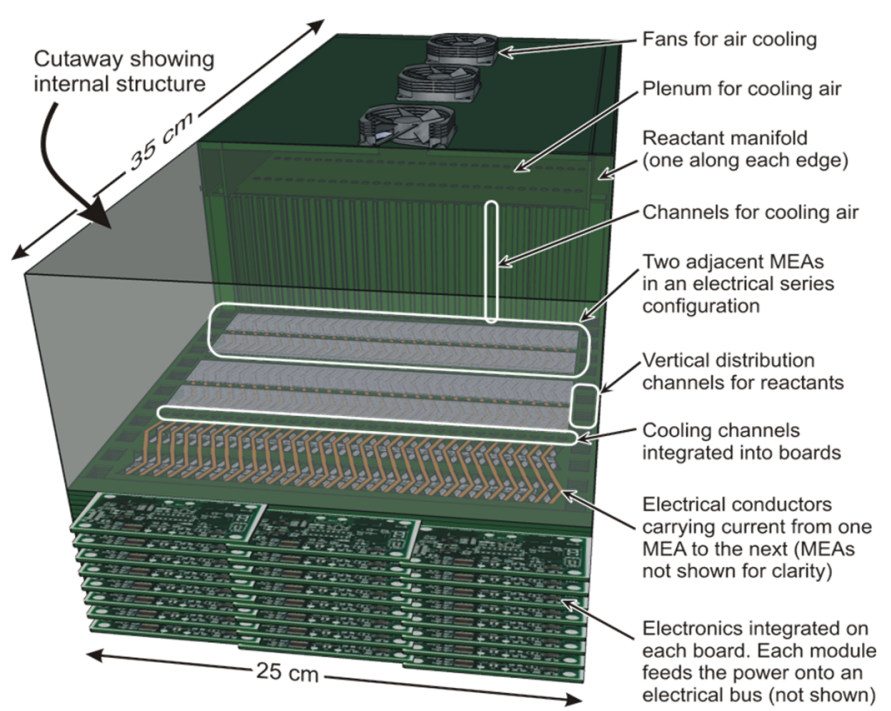

Figure 1. Cutaway illustration showing flexi planar stack and system.

\section{EXPERIMENTAL METHODOLOGY}

Printed circuit board (PCB) manufacturing technology has been shown to be an effective approach for fabricating planar, open cathode polymer electrolyte fuel cells (PEFCs) [1] and for making segmented current collectors and flow fields to analyse fuel cell performance [2]. Flexi planar stacks are fabricated by employing well-established PCB prototyping methods. First, flow field plates are designed and developed with the aid of CAD/CAM software (RoutePro3000) and a computer control drilling and milling machine (Bungard CCD). Serpentine flow field designs are routed on flow field plates using a $1.6 \mathrm{~mm}$ thick PCB material. This consists of a thin copper layer, $35 \mu \mathrm{m}$, laminated on a FR-4 substrate. The latter is a flame retardant type 4 brominated woven glass reinforced epoxy resin system.

The channels and the lands of the flow field have a width of $1 \mathrm{~mm}$. The depth of the channels is set to $1 \mathrm{~mm}$. The flow field plates do not only serve as the substrates for the machining of the channels but they also act as bipolar plates with the copper layer being the current collector. To avoid corrosion of the copper layer in the harsh environment of a PEFC, the PCB surface is covered by a passivation layer of a coating. Manifold and backing plates, 0.4-1.0 mm thick, are machined using uncladded FR-4. The multilayered assembly, shown in Fig. 2, is laminated in a hot press (RMP 210 Bungard) using no-flow prepreg bonding sheets (Isola Group). The press conditions include: applied pressure of $420 \mathrm{PSI}$, temperature range of $130-180^{\circ} \mathrm{C}$ and a curing time of $2 \mathrm{hrs}$.

The current flow field boards can accommodate 5 MEAs. The MEA comprises of a Nafion ${ }^{\mathrm{TM}} 212$ membrane and fuel cell electrodes with a size of $52 \mathrm{~mm} \times 11 \mathrm{~mm}$ and catalyst loading of $0.4 \mathrm{mg}_{\mathrm{Pt}} \mathrm{cm}^{-2}$ (Johnson Matthey, Alfa Aesar catalog \# 45372).

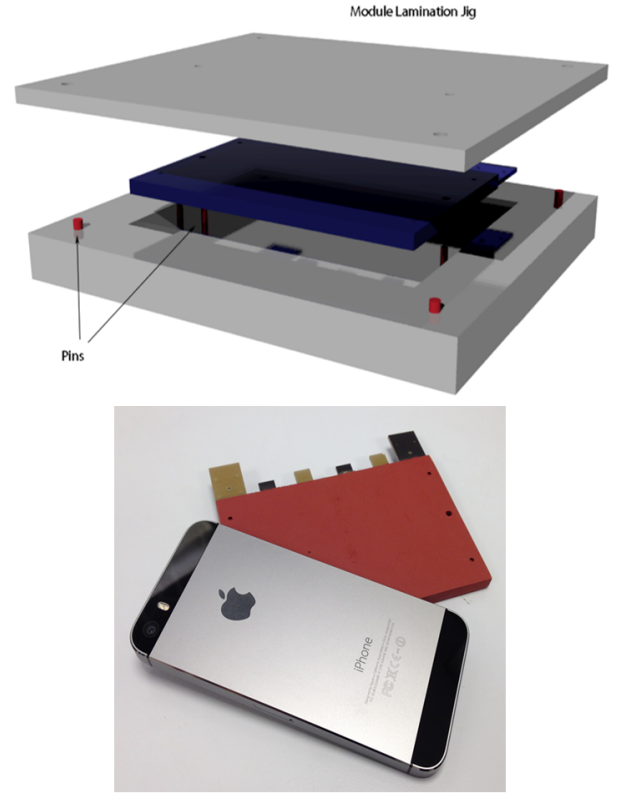

Figure 2. Multilayered flexi planar assembly and lamination jig. A prototype of a flexi planar module is shown on the right.

\section{FLEXI PLANAR PERFORMANCE}

A typical polarisation curve of a 5-MEA flexi planar module is shown in Fig. 3. In the maximum power point, a power density of $12 \mathrm{~W}$ is achieved corresponding to a current density of $877 \mathrm{~mA} / \mathrm{cm}^{2}$.

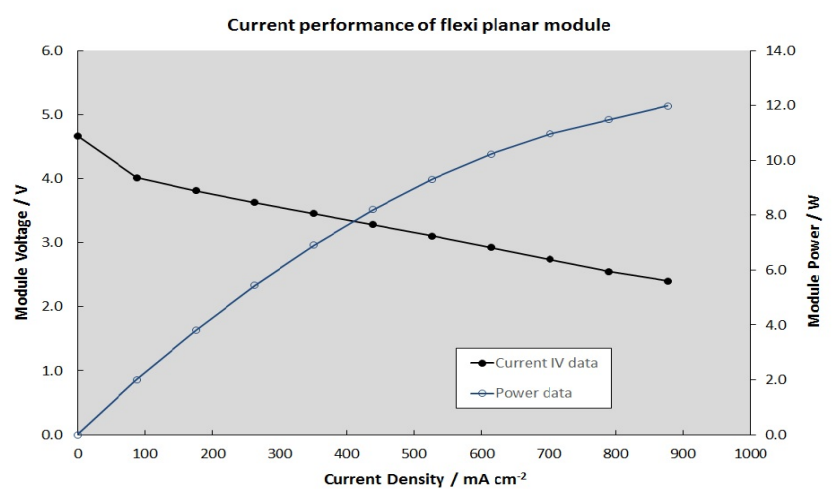

Figure 3. I-V curve and power characteristics of a flexi planar module operated in $\mathrm{H}_{2} /$ Air, stoichs $2 / 2$, Tcell $=80^{\circ} \mathrm{C}$, anode DP \& cathode DP= 79.8 ${ }^{\circ} \mathrm{C}$ and cathode back pressure $=7 \mathrm{PSI}$.

\section{ACKNOWLEDGEMENTS}

We would like to gratefully thank Carbon Trust and Imperial Innovations for sponsoring this project.

\section{REFERENCES}

1. Schmitz A, Wagner S, Hahn R, Uzun H, Hebling C. Stability of planat PEMFC in Printed Circuit Board technology, 2014; 127; p.197.

2. Cleghorn S, Derouin C, Wilson M, Gottesfeld S. A printed circuit board approach to measuring current distribution in a fuel cell, 1998; 28; p. 663. 